\title{
Planning: Too much or too little Politics?
}

\section{Joseph Botting}

Planning failures in less developed countries have been attributed to many factors which may be categorised broadly as administrative incapacity; economic. social. cultural and religious constraints: and political parameters determining plan preparation and performance. It is with the political factors that we are particularly concerned here. These appear to range from capricious, plan-wrecking intervention to non-cooperation, ambiguity in the statement of goals. lack of political will to support necessary but unpopular measures, and a general absence or weakness of the political institutions essential to ensure plan implementation.

A politician, Dr. Eric Williams of Trinidad, has spoken in praise of planning as a good discipline for politicians (Faber and Seers 1972: Vol I). If politics is the art of the possible. he suggests that planning is the science of the possible. The discipline of marrying these two concepts in practical terms is what many politicians find so difficult. Failure of politicians to appreciate the policy implications of a plan has led to independent actions which disturb the planned allocation of resources and ignore its requirements and constraints. A well known example is that of politicians in Kenya encouraging local people to build more Harambee rural secondary schools than the Ministry of Education could staff or equip within the national plan allocation.

National plans have been thrown off course by changes in political priorities during the plan period. Security often becomes a matter of urgency resulting in the diversion of resources from other sectors. In Lesotho social defence planning included an advanced training centre for young offenders. But it had only been in use a few months when the Government commandeered it to accommodate a new armed security police unit. Revolutions, military coups and counter coups are obvious examples of political intervention leading to suspension, abandonment, or at best a distortion of nutional plans.

Foreign policy objectives are admittedly difficult to incorporate in a plan, but can in fact impose constraints on implementation not only by competing for scarce resources but by having the effect of reducing those resources. Trade sanctions against a country on which one's own is economically dependent is one example. Another is provoking retaliatory political sanctions that may result in the cutting off of external aid. Thus Zambia has suffered severe economic consquences from its policies towards Rhodesia and the permanent closing of the border, while Tanzania fell out for a time with Britain and West Germany at the cost of aid and investment.

If foreign policy objectives tend to play something of a maverick role in the planning process, and still more in implementation, there are some domestic objectives that could not easily be built into a plan. These objectives are often of an ideological nature. There may be a political commitment to rapid localisation of posts in the public and private sectors which was not disclosed at the time the plan was formulated. The effects may be a loss of efficiency and control, premature nationalisation of foreign owned industrial. business and commercial undertakings requiring heavy government investment and payment of compensation, and the creation of state trading enterprises more often than not run at a substantial loss. This in turn may lead to a loss of confidence by overseas investors, and a lower rate of domestic investment than was needed to achieve the planned growth target.

Planners should not assume total commitment to rational planning by the governments that hire them. Certainly goals may have been established prior to the planning process. This is particularly true in the case of countrics with a history of colonial dependence. The most important goals are probably nation-building or national integration: establishing the legitimacy of the central government among people more accustomed to parochial loyalties centred on tribal or religious affiliation: political penetration: recruitment and socialisation to enlist popular participation and support: and the management of the new elite roles emerging from the modernisation process. Such goals may be in competition with economic planning objectives in the sense that they may be assigned scarce human, material and financial resources in order to build up the political and administrative institutions required for their achievement. When these political developmental 
goals are uppermost there is a temptation for politicians to proclaim the national plan simply for prestige purposes. Politicians like to be regarded as having a plan for modernisation, progress and reform-a kind of "magic book to brandish at political meetings" (Leys in Faber and Seers 1972: Vol I). But there is little idea that this is more than an electioneering strategy, a set of development slogans or a shopping list of aspirations to which the electorate resonates. Afterwards the plan is left to exist alongside the pragmatic or opportunistic decision-making with which the politician is more familiar.

Political failures in planning should not all be laid at the door of the politicians themselves. Planners also, by their knowledge and expertise, are endowed with a kind of political power. The plans they produce inevitably put constraints on the politicians' power of decision-making. For example, the planners may indicate reduced public expenditure to restore a balance of payments deficit, and this may require fiscal measures and cuts in social services which the politicians know will be extremely unpopular.

The planners may call for politically delicate measures like land reform, greater efficiency and control of tax collection, more equality of opportunity in education, housing and employment, or easier access for rural dwellers to services like medical care which would imply less spending on the urban services. Many such measures would be unacceptable to politicians or the powerful interests on which they depend. They would therefore elicit no more than formal assent with no substantive realisation in practice.

Another example from Tanzania illustrates the problem of conflicting objectives. The planning directorate, located in the President's office, opted for a complete transformation of the colntry's peasant agriculture by the setting up of state farms, collectives and cooperatives. The Ministry of Agriculture thought this was too precipitate and preferred a programme designed to improve existing practices withont radically changing the system (Pratt 1967). The planners prevailed at the negotiating table but the transformation policy, lacking the wholehearted support of the Ministry of Agriculture, was a failure and later abandoned.

This particular case is also an example of the failire of some planners to make a thorough study of departmental policies and programmes in advance. Instead they selest objectives with the aid of the horoscope of their economic growth model rather than from a range of revealed preferences of the political leadership (Leys 1969). At the same time they expect the politicians to abandon or modify their own policies to conform with the plan requirements. The political leaders may give their assent, but experience has shown that this does not necessarily imply commitment. On the contrary when it comes to implementation they may reserve the right to ignore the planners" prescriptions in favour of their own priorities which they may not have made known to the planners in the first place. In some cases it may simply be that they accept some of the plan provisions without fully understanding their implications, and then on finding that they clash with their political preferences feel obliged to ignore them. Either way leads to disarray, with tug-of-war policies by different ministries substituting for the co-ordinated compliance expected by the planners.

Finally there are exogenous constraints on planning. These arise from a range of decisions by foreign governments involving commodity prices, import-export controls, currency manipulation, and political pressures applied by aid donors and investors. There is indeed a sense in which a plan may be partly shaped or its implementation affected by pressures from Washington, London, Moscow, Peking, Geneva oi wherever the OPEC representatives next meet. Becallse of these constraints, Apter (1970) asserts that nodernising societies exist in an essentially hostile world, and the wealthy industrial countries play a 'monitor' role at their expense. For example, if a modernising country manages to increase the production of a primary commodity, the price on the international market is likely to fall.

A consideration of these difficulties may suggest a slightly malevolent role for politics as a variable affecting planning. Another explanation, however, may be too little political intervention rather than too much. In many countries politics in relation to planning has often been haphazard and unpredictable. It has functioned as an intervening variable rather than an independent, determinant variable giving direction and coherence to the whole process of planning and implementation. R. H. Jackson (Hyden, Jackson and Okımu 1970) expresses the view that politics should not be seen as imposing constraints on economic rationality, but as a lever by means of which plans and decisions justified on economic grounds can be implemented. "Planning", he says, "ought therefore to 
incorporate a political theory no less than an economic one, and planners should be guided by political no less than economic knowledge". Myrdal (1969: Vol III) sees plans as political programmes and planning as part of a country's political process. For Hanson (1966) planning is a total process, dealing with economic problems which for their solution demand social changes triggered off by political action. This in turn has a crucial role in ensuring that planned resources are actually used.

A distinction is sometimes made between the political organisational function as against the technical aspect of planning (Leys 1969). The former is concerned with the ways and means of motivating human behaviour necessary to achieve plan objectives. It is important for planners to know in advance the 'price', in terms of incentives, at which people will consent to the changes in attitudes, behaviours and economic activity assumed in the plan. The history of planning shows that this is not often the case. Soil conservation works in Lesotho consistently failed to engage the 'activators' which would have led to their acceptance by peasant farmers. They were too complicated for the people to understand. They appeared to provide no direct benefits or short term results. They were introduced from above by officials with a mixture of persuasion and threats without adequate efforts to obtain the views of the farmers in advance or to secure their initial participation in planning the schemes.

The harmful consequences of too little politics in planning may be seen in different ways in Tanzania and India. At independence in 1961 the Tanzania African National Union (TANU) anchored itself firmly to a socialist ideology and announced that this would be the guiding principle in its development planning. Unfortunately, however, Tanzanian socialism did not at that time go much beyond a philosophical enunciation. The party produced no planning policy or objectives to implement its socialist creed other than its proclamation of hard work, freedom and unity-Uhuru na Kazi and Uhuru na Umoja. The expatriate planners therefore worked within the conventional framework of industrial development, attracting investment of any type, and agricultural improvement. The result was quite contrary to the aims of TANU, however imprecisely expressed. Social and economic inequality was being reinforced by the emergence of an African commercial and professional middle class and, in the rural areas, prosperous smallholder farmers. The early years of the first plan also helped to preserve the inherited tripartite division, European, Asian, African, in that economic and social order. The retention of most of the colonial capitalist structures-a 'Trojan horse within the socialist camp' (Saul 1971) - was leading inevitably to the creation of a capitalist society within a socialist professing State. Thus there was "a rhetorical commitment to socialist objectives, a technical commitment to 'neutral' policy tools, and a practical achievement of capitalist results" (Van Arkadie 1972).

In India the case was somewhat different. The Congress Party committed itself to socialism, but also to democratic and non-authoritarian procedures. This twin commitment has had contradictory effects on the planning process. On the one hand the political emphasis on social and distributive justice created pressures to give priority to rural welfare amenities at the expense of more realistic economic policies, pushing the planners towards achieving the Welfare State simultaneously with or actually ahead of the establishment of the economic base to sustain it. There was also a bias towards labour at the expense of management, which led to indiscipline in the public and private sectors, and a socialist disapproval of 'profits' which discouraged risktaking in the private sector and prompted a high degree of nationalisation accompanied by rising costs and loss of efficiency (Prasad in Faber and Seers 1972: Vol I1).

On the other hand a commitment to democratic consultation and participation gave rise to an almost bewildering array of organised group, caste and class pressures on the planners, particularly at the states level, where demands were made for even more decentralisation so that local needs might be more effectively represented. The political strength of the states was thus augmented, especially against the already hard-pressed centre. Failure to manage such pressures led to departures from economic rationality and exaggerated plan projections to try to please everyone (Streeten and Lipton 1968). In the midst of all this big business interests managed to exercise a considerable degree of control over the socialist policies of the Congress Party (Hanson 1966). The result has been a contradiction between political profession and behaviour, and the appearance in the plans of unrealistic assumptions and ideological exhortations in place of firmly based measures to achieve the targets. Radical commitments and reform goals have been stated far in advance of actual policies, which in fact have turned out to be more conservative than socialist (Myrdal 1971). 
Reluctance to use controls to bring about the radical changes necessary for redistribution of wealth leads to a deteriorating situation and the emergence of the 'soft' State or the price indeterminacy of Riggs' 'prismatic' society (Riggs 1964), in which people are largely left to do what they please-or what they have the means to do. Inevitably this results in the extension and consolidation of the power of the wealthy elites who may comfortably assent to their government's socialist ideology while doing nothing about the continued exploitation, deprivation, political apathy and alienation of the poor majority.

The dangers and paradoxes inherent in the state of affairs outlined above were perceived in the course of Tanzania's first plan period in the mid-1960s and led to political, structural, administrative and planning changes aimed at getting the nation back on to a socialist course. The first step was the political unification of Tanzania as a one-party State under the leadership of President Nyerere and TANU. Next came a clear statement of political objectives set out in the Arusha declaration of 1967, emphasizing public ownership, rural development, and selfreliance in place of excessive dependence on external sources of finance. Immediate steps were taken to implement the declaration. Rural development was to be promoted by bringing scattered farm households together in ujumaa villages where people farm the land cooperatively and set up village institutions for planning and implementation of improvements. TANU was reorganised to enable it to function through village cells, district and regional executive committees linked to the National Executive at the centre. Guidelines-Mwongozo-were issued establishing the supreme policy-making role of TANU but at the same time insisting on a planning role for the ordinary people. "If development is to benefit the people, the people must participate in considering, planning and implementing their development plans. The duty of our party is to ensure that the leaders and experts implement the plans that have been agreed by the people themselves." (Mwongozo 1971).

These political institutional reforms were set within a new framework of planning and administrative decentralisation which began in 1972. At all levels TANU is powerfully represented through its organisational tiers and all plans have to be approved by the party before going to the central planning agency.
It remains to be seen whether these changes have provided the right mix for more realistic, participatory planning and effective implementation. If the hopes of TANU are fulfilled, Tanzania's system could offer a model for other Third World country governments who wish to translate their political professions of socialism into planning reality.

\section{References}

Apter, D., 1971, Choice and the Politics of Allocation, Yale University Press, New Haven and London

Arrighi, G. and J. S. Saul, 1968, 'Socialism and Economic Development in Tropical Africa', Journal of Modern African Studies, VI, August

Faber, M., and D. Seers, 1972, Crisis in Planning (2 vols), Chatto and Windus, London

Hanson, A. H., 1966, The Process of Planning, OUP, Oxford

Hyden, E., R. Jackson and J. Okumu (eds.), 1970, Development Administration: the Kenyan Experience, OUP, Oxford

Leys, C. (ed.), 1969, Politics and Change in Developing Countries, CUP, Cambridge

Mwongozo, 1971, Tanzanian National Union (TANU), Government Printer, Dar es Salaam

Myrdal G., 1969, Asian Drama (3 vols), Pelican, Harmondsworth

Myrdal, G., 1971, Challenge of World Poverty, Penguin, Harmondsworth

Nyerere, J. K., 1972, 'Decentralisation', (mimeo), Dar es Salaam

Pratt, R. C., 1967, 'Administration of Economic Planning in a Newly Independent State: the Tanzanian Experience', Journal of Commonwealth Political Studies, 5

Riggs, F. W., 1964, Public Administration in Developing Countries, Houghton Mifflin, Boston

Saul, J. S., 1972, 'Political Economy of Planning in Tanzania', Development and Change, 1:3

Streeten, P., and M. Lipton, 1968, The Crisis in Indian Planning, OUP, Oxford

Uchumi Editorial Board, 1972, Towards Socialist Planning, Tanzania Publishing House, Dar es Salaam

Waterston, A., 1965, Development Planning: Lessons of Experience, Johns Hopkins, Baltimore 